\title{
STUDI KELAYAKAN BISNIS KONTEN KREATIF DI KOTA BANDUNG (STUDI KASUS: PT AKSES NUSA KARYA INFRATEK)
}

\section{FEASIBILITY STUDY OF CREATIVE CONTENT BUSINESS IN BANDUNG CITY (CASE STUDY: PT AKSES NUSA KARYA INFRATEK)}

\author{
Siti Hajar Komariah, Dicky Hidayat \\ Fakultas Industri Kreatif, Universitas Telkom \\ sitihajarkomariah@telkomuniversity.ac.id \\ dicky@tcis.telkomuniversity.ac.id
}

\begin{abstract}
Abstrak--Pertumbuhan ekonomi kreatif Indonesia dari tahun 2006 hingga 2009 tercatat 2,9\% per tahun dengan rata-rata pertumbuhan industri kreatif di Indonesia sebesar 6,5\% padahal rata-rata negara di ASEAN hanya $5 \%$ (Pusat data Republika, 20 Januari 2012). Kota Bandung, sebagai tempat lahir dan tumbuhnya PT ANK Infratek, bahkan terpilih dalam 5 besar kota kreatif seAsia. Hal tersebut berdasarkan sebuah survei yang dilakukan oleh salah satu media di Singapura yakni Channel News Asia pada Desember 2011 lalu. (Detik Bandung, Februari 2012). Industri kreatif di Indonesia cukup signifikan berkontribusi pada PDB negara. Hal ini dapat dilihat pada Gambar 1.2. Sementara itu indikator pertumbuhan ekonomi kreatif dapat dilihat pada Tabel. Bahkan pada tahun 2014, industry kreatif tumbuh pesat di Indonesia dari target 10\%, di akhir 2014 pertumbuhannya mencapai angka $12,2 \%$. Industri Kreatif merupakan jenis bisnis baru yang belum pernah dilakukan di PT ANK Infratek dan PT PT ANK Infratek berencana ingin mengimplementasikan dan menjalankan bisnis ini. Oleh karena itu analisis kelayakan bisnis perlu dilakukan untuk mengetahui tingkat kelayakan dari bisnis industri kreatif ini jika ditinjau dari aspek pasar, aspek teknis, aspek keuangan kemudian dilakukan analisis sensitivitas. Berdasarkan analisis dari aspek-aspek tersebut dapat diperoleh kesimpulan mengenai tingkat kelayakan implementasi bisnis industri kreatif ini oleh PT ANK Infratek
\end{abstract}

Kata kunci: Interactive Game, Industri Kreatif, Studi Kelayakan.
Abstract--Indonesia's creative economy growth from 2006 to 2009 was recorded at $2.9 \%$ per year with the average growth of creative industry in Indonesia at $6.5 \%$ while the average country in ASEAN only 5\% (Republika data center, January 20 2012). Bandung, as the birthplace and the growth of PT ANK Infratek, even elected in the top 5 creative cities in Asia. This is based on a survey conducted by one of the media in Singapore, Channel News Asia in December 2011 ago. (Detik Bandung, February 2012). The creative industry in Indonesia is significant enough to contribute to the country's GDP. This can be seen in Figure 1.2. Meanwhile, the indicators of creative economic growth can be seen in Table 1.1. Even in 2014, creative industry grew rapidly in Indonesia from the target of 10\%, at the end of 2014 the growth reached $12.2 \%$. Creative industry is a new type of business that has never been done in PT ANK Infratek and PT PT ANK Infratek plans to implement and run this business. Therefore, business feasibility analysis needs to be done to find out the feasibility level of this creative industry business when viewed from the market aspect, technical aspect, financial aspect and then conducted sensitivity analysis. Based on the analysis of these aspects can be obtained conclusions about the level of feasibility of this creative industry business implementation by PT ANK Infratek

Keywords: Interactive Game, Creative Industry, Feasibility Study. 


\section{PENDAHULUAN}

Industri Kreatif dapat diartikan sebagai kumpulan aktivitas ekonomi yang terkait dengan penciptaan atau penggunaan pengetahuan dan informasi. Nama lain dari Industri kreatif adalah Industri Budaya ${ }^{[1]}$ atau juga Ekonomi Kreatif ${ }^{[2]}$. Dengan kata lain, industri kreatif adalah proses mengeksploitasi keterampilan, daya kreasi dan daya cipta individu untuk menghasilkan lapangan pekerjaan dan kesejahteraan. ${ }^{[3]}$

Menurut Howkins, ada beberapa bidang pekerjaan dan produk yang masuk dalam kategori Ekonomi Kreatif, diantaranya film, musik, seni pertunjukkan, desain, fashion, mainan dan permainan, permainan video $^{[2]}$ periklanan, arsitektur, kerajinan, penerbitan, penelitian dan pengembangan (R\&D), perangkat lunak, Televisi dan Radio. Beberapa pihak berpendapat: "Kreativitas manusia adalah sumber daya ekonomi utama." ${ }^{[4]}$ dan "Industri abad kedua puluh satu akan tergantung pada produksi pengetahuan melalui kreativitas dan inovasi." [5]

Sejak tahun 2010, pertumbuhan industri kreatif di Indonesia rata-rata sebesar 6,5\% per tahun (Pusat data Republika, 20 Januari 2012) melebihi rata-rata pertumbuhan industri kretaif negara-negara di ASEAN yang hanya $5 \%$. Bahkan, pada tahun 2014, industri kreatif di Indonesia tumbuh pesat mencapai $12,2 \%$ dari target $10 \%$. Seiring dengan pertumbuhannya, kontribusi industri kreatif di Indonesia terhadap PDB negara cukup signifikan. Hal ini dapat dilihat pada Gambar 1.2. Sementara itu indikator pertumbuhan ekonomi kreatif dapat dilihat pada Tabel 1.

TABEL 1

INDIKATOR EKONOMI KREATIF INDONESIA

\begin{tabular}{|l|c|c|c|c|c|c|}
\hline INDIKATOR & 2006 & 2007 & 2008 & 2009 & $\mathbf{2 0 1 0}$ & $\begin{array}{c}\text { Rata-rata } \\
5 \text { tahun }\end{array}$ \\
\hline \hline $\begin{array}{l}\text { Pertumbuhan } \\
\text { Industri Kreatif }\end{array}$ & $4,95 \%$ & $2,73 \%$ & $-0,50 \%$ & $2,27 \%$ & $6,03 \%$ & $3,10 \%$ \\
\hline $\begin{array}{l}\text { Kontribusi Ekonomi } \\
\text { Nasional }\end{array}$ & $7,69 \%$ & $7,42 \%$ & $6,97 \%$ & $7,03 \%$ & $7,29 \%$ & $7,28 \%$ \\
\hline $\begin{array}{l}\text { Jumlah Tenaga Kerja } \\
\text { juta orang) }\end{array}$ & 7,009 & 7,375 & 7,624 & 8,207 & 8,553 & 7,75 \\
\hline $\begin{array}{l}\text { Partisipasi Tenaga } \\
\text { Kerja Nasional }\end{array}$ & $7,34 \%$ & $7,38 \%$ & $7,43 \%$ & $7,83 \%$ & $7,90 \%$ & $7,58 \%$ \\
\hline $\begin{array}{l}\text { Jumlah Perusahaan } \\
\text { (juta perusahaan) }\end{array}$ & 2,576 & 2,835 & 3,035 & 3,225 & 3,350 & 3,00 \\
\hline $\begin{array}{l}\text { Nilai Ekspor Industri } \\
\text { Kreatif (juta rupiah) }\end{array}$ & 84.840 & 95.209 & 114.925 & 116.651 & 131.251 & 108.575 \\
\hline $\begin{array}{l}\text { Kontribusi Ekspor } \\
\text { Industri Kreatif }\end{array}$ & $9,33 \%$ & $8,86 \%$ & $7,52 \%$ & $10,65 \%$ & $9,25 \%$ & $9,12 \%$ \\
\hline $\begin{array}{l}\text { Nilai Impor Industri } \\
\text { Kreatif (juta rupiah) }\end{array}$ & 6.045 & 8.077 & 10.442 & 15.491 & 16.262 & 11.263 \\
\hline $\begin{array}{l}\text { Kontribusi Impor } \\
\text { Industri Kreatif }\end{array}$ & $1,10 \%$ & $1,15 \%$ & $0,82 \%$ & $1,70 \%$ & $1,33 \%$ & $1,22 \%$ \\
\hline $\begin{array}{l}\text { Net Trade } \\
\text { (juta rupiah) }\end{array}$ & 78.795 & 87.131 & 104.483 & 101.161 & 114.989 & 97.312 \\
\hline
\end{tabular}

Pertumbuhan dan perkembangan industri kreatif ini mendapat perhatian besar dari beberapa perusahaan untuk segera melirik berbisnis di bidang yang menarik ini. Salah satunya adalah PT. Akses Nusa Karya Infratek sebagai salah satu main contactor nya PT. Telkom dan PT. Indosat, yang kebetulan lahir di dirikan dan tumbuh berkembang di Kota Bandung, dimana berdasarkan hasil dari sebuah survei yang dilakukan oleh Channel News Asia Singapura pada Desember 2011, Kota Bandung terpilih dalam 5 besar kota kreatif se-Asia. (Detik Bandung, Februari 2012).

Perubahan dan tantangan peta bisnis ini disikapi PT ANK Infratek sebagai sebuah tantangan dan keajaiban. Bagi PT ANK Infratek, ini adalah tantangan sekaligus peluang untuk memulai bisnis di industri kreatif ini. Jika sebelumnya dikenal sebagai kontraktor penggelaran jaringan fiber optik perusahaan telekomunikasi, mengawali tahun 2016, PT ANK Infratek bertekad untuk mulai merambah kepada bidang bisnis industri kreatif. Bisnis konten dianggap mempunyai potensi pasar yang sangat besar dan luas sehingga berpeluang besar untuk dijalankan.

Departemen Perdagangan Republik Indonesia sudah membuat pemetaan industri kreatif, dimana bidangbidang yang termasuk dalam sub-sektor industri berbasis kreativitas di Indonesia adalah: Periklanan, Arsitektur, Pasar Barang Seni, Kerajinan, Desain, Fesyen, Video, Film dan Fotografi, Permainan Interaktif, Musik, Seni Pertunjukan, Penerbitan dan Percetakan, Layanan Komputer dan Piranti Lunak, Televisi dan Radio, Riset dan Pengembangan, dan Kuliner.

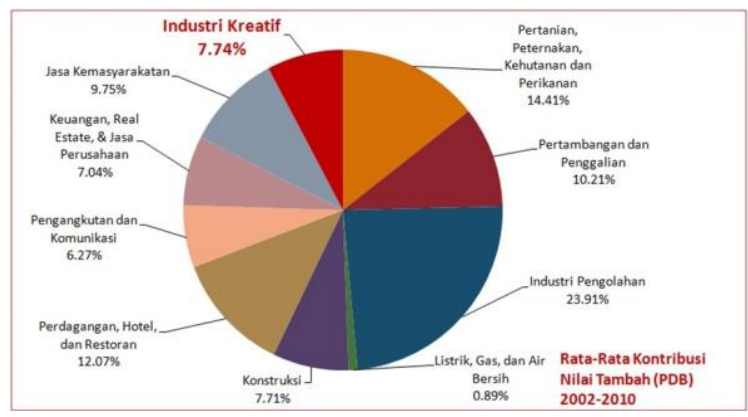

Gambar 1. Kontribusi Industri Kreatif pada PDB Nasional

Jenis industri kreatif yang mulai menjadi target rencana pengembangan PT ANK Infratek adalah Research and Development (R\&D), E-Learning, Advertising, Design, Film, Video, Interactive Games, TV dan Radio $^{[2]}$. Pengembangan produk konten yang akan dimulai dikembangkan oleh PT ANK Infratek dalam tahap pertama adalah pengembangn konten Interactive Games berbasis android. Produk ini dipilih dengan pertimbangan jumlah pengguna internet dan pemilik gadget cerdas terus meningkat signifikan dari tahun ke tahun, dimana salah satu konsumsi tertinggi yang akses oleh para penggunanya adalah interactive game. Selain

Studi Kelayakan Bisnis Konten Kreatif Di Kota Bandung (Studi Kasus: PT Akses Nusa Karya Infratek) Siti Hajar Komariah, Dicky Hidayat (Hal: 7-15) 
itu, dari hasil penelitian sebelumnya, produk game lokal hasil karya anak bangsa cukup dikenal dan diminati oleh para penggunanya. [6]

Industri Kreatif merupakan jenis bisnis baru yang belum pernah dilakukan di PT ANK Infratek dan PT PT ANK Infratek berencana ingin mengimplementasikan dan menjalankan bisnis ini. Oleh karena itu analisis kelayakan bisnis perlu dilakukan untuk mengetahui tingkat kelayakan dari bisnis industri kreatif ini jika ditinjau dari aspek pasar, aspek teknis, aspek keuangan kemudian dilakukan analisis sensitivitas. Berdasarkan analisis dari aspek-aspek tersebut dapat diperoleh kesimpulan mengenai tingkat kelayakan implementasi bisnis industri kreatif ini oleh PT ANK Infratek.

\section{STUDI LITERATUR}

A. Gambaran Objek Penelitian

PT. Akses Nusa Karya Infratek (ANK Infratek) adalah sebuah perusahaan Swasta Nasional bergerak dalam bidang pelayanan jasa teknis, Perdagangan Umum khususnya bidang Telekomunikasi, Elektrikal dan Industri. PT ANK didirikan secara resmi pada 2 Juni 2008 di Bandung.

Salah satu kekuatan kompetensi ANK Infratek adalah SDM yang berkualitas dan berpengalaman di bidangnya masing-masing serta memiliki pengetahuan dan wawasan menyeluruh terutama di bidang Telekomunikasi.

PT. ANK Infratek memulai usaha dengan tujuan untuk menawarkan suatu tingkatan baru pada efesiensi, kreatifitas dan kemitraan pada produk dan jasa yang ditawarkan. Prinsip PT. ANK Infratek adalah dengan membagi pengetahuan dan pengalaman, dapat bersinergi dalam meningkatkan performa, kehandalan dan efesiensi pengeluaran pada sistem dan produk yang dibutuhkan.

Motto dari PT. ANK Infratek adalah dari sekian permasalahan teknis dan manajemen yang customer hadapi dan berhubungan dengan bidang keahlian perusahaan, PT. ANK Infratek dapat memberikan peluang dan turut membantu menyelesaikannya.

Dalam kegiatan bisnisnya PT. ANK Infratek berusaha mengembangkan kegiatan-kegiatan bisnis dalam bidang :

1. Pekerjaan Jaringan Fiber Optik \& Jaringan Kabel Sekunder (OSP), Instalsasi Hardware \& Software dan Mechanical Electrical.

2. Pengadaan Barang dan Jasa untuk Industri Telekomunikasi.

3. Pengadaan Barang dan Jasa Industri Oil and Gas.

4. Pengembangan Jasa dan Konten Industri Kreatif (Dalam tahap inisiasi dan studi kelayakan)

Sasaran usaha PT. ANK Infratek Dalam upaya untuk meningkatkan usahanya khususnya di bidang jasa pembangunan OSP dan infrastruktur serta pendukung lainnya yang berfungsi dalam pengoperasian system telekomunikasi bergerak selular maupun fixed Phone, dan Pengadaan Barang dan Jasa untuk indutri Oil and Gas terutama kepada operator-operator utama, di Indonesia antara lain:
1. PT. Telkom Tbk
2. PT. Indosat
3. PT. Aplikanusa Lintasarta
4. PT. Telkomsel
5. PT. Excelcomindo Pratama
6. PT. Bakrie Telecom
7. PT. Smartfren
8. PT. Medco Energi

\section{B. NPV (Net Present Value)}

Net Present Value (NPV) merupakan selisish antara pengeluaran dan pemasukan yang telah didiskon dengan menggunakan social opportunity cost of capital sebagai faktor diskon. Dalam kriteria seleksi kuantitatif, metode net present value seringkali dianggap metode yang paling baik sehingga sering digunakan untuk menilai kelayakan suatu usulan investasi. Nilai present value (PV) yang dijumlahkan selama masa hidup dari proyek dapat dihitung dengan persamaan $1 .{ }^{[8\}[9]}$

$P V=R_{t} /(1+i)^{t}$

$\mathrm{t}:$ arus waktu kas

$\mathrm{i}$ : suku bunga diskonto yang digunakan

$\mathrm{R}_{\mathrm{t}}$ : arus kas bersih (the net cash flow) dalam waktu $\mathrm{t}$

Atau dengan menggunakan

$\mathrm{NPV}=\mathrm{PV}$ Benefit $-\mathrm{PV}$ Cost

$\mathrm{NPV}=\sum_{n=0}^{N}(\mathrm{Rn}-\mathrm{Cn})(\mathrm{p} / \mathrm{f}, \mathrm{i} \% \mathrm{n})$

$\mathrm{Rn}:$ arus kas masuk

$\mathrm{Cn}$ : arus kas keluar

( $\mathrm{p} / \mathrm{f}, \mathrm{i} \% \mathrm{n})$ : faktor present dan future dengan suku bunga $i \%$

Kriteria pengambilan keputusan sebagai berikut ${ }^{[8][9] \text { : }}$

1. Jika NPV > 0 maka investasi yang dilakukan memberikan manfaat kepada perusahan.

2. Jika NPV < 0 maka investasi yang dilakukan menimbulkan kerugian pada perusahaan.

3. Jika NPV $=0$, maka investasi yang dilakukan tidak menimbulkan keuntungan dan kerugian pada perusaahan.

\section{IRR (Internal Rate of Return)}

IRR merupakan indikator tingkat efisiensi dari suatu investasi dengan kata lain IRR adalah nilai discount rate yang membuat NPV dari proyek sama dengan nol. Discount rate yang dipakai untuk mencari present value suatu biaya atau benefit harus senilai dengan opportunity 
cost of capital seperti yang terlihat dari sudut pandang penilaian proyek. Suatu proyek sapat dilakukan apabila laju pengembaliannya lebih besar daripada laju pengembalian jika investasi dilakukan di tempat lain (bunga deposito bank, reksadana, dan lain-lain).

IRR dapat digitung dengan menggunakan persamaan 3 .

$$
\begin{gathered}
\text { PW of Benefit }=\mathrm{PW} \text { of Cost } \\
\sum_{n=0}^{N}(\mathrm{Rn}-\mathrm{Cn})(\mathrm{p} / \mathrm{f}, \mathrm{i} \% \mathrm{n})=\sum_{n=0}^{N}(C n)(p / f, i \% n) \\
I R R=\mathrm{i} 2 \frac{P V 1(I 2-I 1)}{\mathrm{PV} 2-\mathrm{PV} 1} \ldots \ldots \ldots \ldots \ldots \ldots \ldots \ldots \ldots \ldots \ldots \ldots \ldots
\end{gathered}
$$

\section{Payback Period}

Payback period merupakan suatu metode yang digunakan untuk menghitung berapa lama waktu yang diperlukan sampai nilai investasi kembali (balik modal). Metode ini tidak digunakan sebagai alat utama melainkan hanya sebagai faktor indikator dari likuiditas dan risiko investasi.

Perhitungan payback period, dapat dilakukan dengan menggunakan persamaan 4 .

Payback period $=t+\frac{x-z}{y-z} \times 1$ tahun

Payback period $=\frac{\text { Initial investement }}{\text { Cash Flow }} \times 1$ tahun

\section{Keterangan}

$\mathrm{t}=$ tahun terkahir dimana arus kas masih belum bisa menutupi initial investement

$\mathrm{x}=$ jumlah initial investement

$\mathrm{z}=$ jumlah kumulatif arus kas pada tahun ke-n

$\mathrm{y}=$ jumlah kumulatif arus kas pada tahun ke-n+1

\section{METODE PENELITIAN}

Penelitian dilakukan dengan melakukan studi literature dari berbagai sumber seperti buku, penelitian sebelumnya dan data-data sekunder terkait bisnis industry kreatif dan survey potensi pasar industru kreatif di Kota Bandung.

Adapun metode pendekatan yang digunakan dalam studi ini adalah:

1. Studi kepustakaan untuk mendapatkan data/informasi tentang industry kreatif dan perkembangan bisnisnya.

2. Pemanfaatan data primer (hasil wawancara dengan manajemen/ahli dan survey pasar) dan data sekunder untuk penghitungan peramalan potensi pasar dari bisnis industri kreatif di Kota Bandung.
3. Penghitungan parameter kelayakan dari bisnis tersebut berdasarkan teori keekonomian. ${ }^{[8][9] .}$

\section{IV.PENGUMPULAN DAN PENGOLAHAN DATA}

A. Aspek Pasar

Pengembangan produk konten yang akan dimulai dikembangkan oleh PT ANK Infratek dalam tahap pertama adalah pengembangn konten Interactive Games berbasis android. Untuk mendukung pemasaran produk konten interakctive games berbasis android ini, layanan operator yang diperlukan harus sudah mempunyai layanan jaringan $3 \mathrm{G}$ ke atas. Dengan mempertimbangkan level layanan dan kualitas jaringan yang dimiliki, pelanggan telkomsel dapat dijadikan sample untuk menentukan potensi aspek pasar dari salah satu layanan data ini.

\section{B. Pengumpulan Data Pasar}

PT Telkomsel membagi menjadi tiga area untuk wilayah Jawa Barat, yaitu branch Bandung, branch Tasikmalaya dan branch Cirebon. Terdapat sub area untuk masing-masing branch, subbranch untuk Bandung terdiri dari Kota Bandung, Kabupaten Bandung, Bandung Barat, Cianjur, Cimahi, dan Sumedang. Berdasarkan penggunaan jaringan, maka dibedakan menjadi dua pengguna yaitu pengguna $2 \mathrm{G}$ dan $3 \mathrm{G} / 4 \mathrm{G}$. Penggunaan jaringan $2 \mathrm{G}$ dan $3 \mathrm{G}$ dapat dilihat pada Gambar 2 .

\section{PENGGUNAAN JARINGAN 2 G DAN 3 G}

\section{BANDUNG}

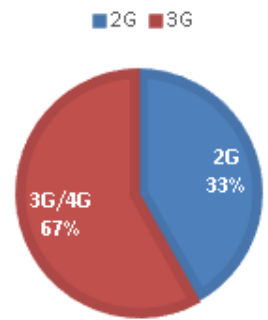

Sumber : PT Telkomsel, 2016

\section{Gambar 2. Prosentase pengguna jaringan di Bandung}

Dari Gambar 2 di atas, dapat diketahui bahwa pengguna jaringan $3 \mathrm{G} / 4 \mathrm{G}$ yang identik dengan pengguna layanan data di Bandung lebih banyak daripada pengguna jaringan 2G. Hal ini mengindikasikan area Bandung dapat menjadi daerah potensial untuk pemasaran berbagai layanan data termasuk layanan aplikasi games.

Berdasarkan data di atas, maka data pasar 3G/4G diperoleh dari data historis yaitu berdasarkan pengguna jaringan 2G/3G Telkomsel di wilayah Bandung. Data historis yang diperoleh adalah pengguna jaringan $3 \mathrm{G}$ per bulan selama pertengahan tahun 2015 sd 2016. Data

Studi Kelayakan Bisnis Konten Kreatif Di Kota Bandung (Studi Kasus: PT Akses Nusa Karya Infratek) Siti Hajar Komariah, Dicky Hidayat (Hal: 7-15) 
pengguna 3G tahun 2015/2016 dapat dilihat pada Tabel 2.

Berdasarkan data historis di atas dapat dilakukan peramalan terhadap pengguna $3 \mathrm{G} / 4 \mathrm{G}$ pada tahun-tahun berikutnya. Peramalan pengguna 3G /4G dilakukan per bulan dengan pemilihan metode peramalan berdasarkan ( Standart Estimate Error ) SEE yang terkecil. Setelah didapatkan peramalan pengguna jaringan $3 \mathrm{G} / 4 \mathrm{G}$, berdasarkan penentuan pasar potensial, maka dapat dihitung revenue untuk masing-masing kelas layanan pengguna. Revenue dihitung berdasarkan pengguna layanan 3G dikali dengan tarif yang diberlakukan untuk memperoleh aplikasi games.

TABEL 2

DATA HISTORIS PENGGUNA 3G PT TELKOMSEL

\begin{tabular}{|r|r|}
\hline \multicolumn{1}{|c|}{ Tahun } & Pengguna(user) \\
\hline Jul-15 & 2.727 .900 \\
\hline Agust-15 & 2.770 .720 \\
\hline Sep-15 & 2.813 .540 \\
\hline Okt-15 & 2.856 .360 \\
\hline Nop-15 & 2.899 .180 \\
\hline Des-15 & 2.942 .000 \\
\hline Jan-16 & 2.984 .820 \\
\hline Feb-16 & 3.027 .640 \\
\hline Mar-16 & 3.070 .460 \\
\hline Apr-16 & 3.113 .280 \\
\hline Mei-16 & 3.156 .100 \\
\hline Jun-16 & 3.198 .920 \\
\hline
\end{tabular}

Sumber: PT Telkomsel, 2016

\section{Segmentasi Pelanggan}

Pengguna 3G/4G terbagi menjadi dua segmen, yaitu segmentasi kelas bisnis dan residensial. Penentuan segmentasi ditentukan berdasarkan faktor demografi penduduk kota Bandung. Tujuan dari segmentasi pengguna ini adalah untuk menentukan kebutuhan trafik jaringan. Karateristik untuk masing-masing kelas adalah:

a. Kelas Bisnis

Kelas bisnis merupakan segmentasi pengguna yang mempunyai karateristik konsumtif, terdiri dari pengguna yang sudah bekerja, sering menggunakan internet untuk kebutuhan pribadi maupun pekerjaan, data rate mencapai 2 Mbps.

b. Kelas Residensial

Kelas resindensial merupakan pengguna yang tidak terlalu sering dan tidak terlalu boros dalam menggunakan internet, penggunaan internet hanya untuk kebutuhan pribadi, sehingga penggunaan trafik lebih hemat, data rate sebesar $256 \mathrm{Kbps}-1$ Mbps.

D. Pembagian Jenis Layanan

Pembagian jenis layanan game interaktif pada jaringan $3 \mathrm{G} / 4 \mathrm{G}$ bertujuan untuk mengetahui trafik masing-masing pengguna dalam mengakses games. Jenis layanan $3 \mathrm{G} / 4 \mathrm{G}$ yang akan digunakan oleh pengguna terbagi atas dua layanan, yaitu:

a. Full Level

Layanan Full level merupakan layanan yang prioritas dan istimewa dibandingkan dengan layanan yang lain, sehingga layanan ini lebih ditujukan kepada segmen bisnis. Layanan Full Level diasumsikan mempunyai kebutuhan layanan kecepatan data lebih tinggi dan lebih boros. Tingkat Service Level Agreement (SLA) maksimum sebesar 2 Mbps. Distribusi pengguna Full Level diasumsikan moderate karena harga layanan yang lebih mahal. Pengguna bisnis diasumsikan lebih tertarik karena mempunyai kemampuan untuk membayar. Dari pendekatan dan asumsi yang diperoleh, maka pembagian pengguna untuk layanan Full adalah kelas bisnis $60 \%$ dan residensial $40 \%$. Sehingga distribusi pembagian pengguna dapat memenuhi asumsi.

b. Half Level

Layanan Half Level ditujukan kepada pengguna residensial karena lebih murah dibandingkan layanan Gold dan kebutuhan kecepatan data lebih rendah. Tingkat Service Level Agreement (SLA) maksimum sebesar 1 Mbps. Distribusi pengguna layanan diasumsikan optimis karena mempertimbangkan kompetisi antar operator yang menyebabkan pengguna akan memilih tarif yang lebih murah. Asumsi pengguna layanan Half level untuk masing-masing segmen pengguna adalah pengguna bisnis 10\% dan residensial $90 \%$.

E. Perhitungan Peramalan Pengguna 3G/4G PT Telkomsel di Bandung

Peramalan permintaan (demand forecasting) merupakan hal yang penting dalam perencanaan strategi implementasi teknologi. Hal ini menjadi penentu dalam penentuan jumlah perangkat yang akan digunakan dan akan berimbas pada perhitungan keuangan. Sehingga studi pasar yang dilakukan harus hati-hati supaya perhitungan yang dilakukan tidak berbeda jauh dengan kondisi yang ada termasuk dalam pemilihan metode peramalan.

TABEL 3

PERAMALAN PENGGUNA 3G/4G SELAMA LIMA TAHUN

\begin{tabular}{|c|r|}
\hline Tahun & Jumlah pengguna \\
\hline 2016 & 5.024 .296 \\
\hline 2017 & 5.977 .809 \\
\hline 2018 & 7.112 .327 \\
\hline 2019 & 8.462 .133 \\
\hline 2020 & 10.068 .119 \\
\hline
\end{tabular}


Metode peramalan yang digunakan dalam peramalan pengguna Telkomsel adalah metode konstan karena mempunyai nilai SEE terkecil. Peramalan pengguna 3G/4G Telkomsel di Bandung menggunakan pertumbuhan pengguna 2G/3G di Bandung. Berdasarkan data historis diketahui rata-rata pertumbuhan pengguna 3G selama tahun 2015/2016 adalah 15.6\%, karena pertumbuhan pengguna $3 \mathrm{G}$ sangat kecil maka hasil perhitungan peramalan mendekati konstan.Perhitungan pengguna $3 \mathrm{G}$ dilakukan per bulan hingga lima tahun kemudian dijumlahkan, sehingga diperoleh jumlah pengguna per tahun seperti Tabel 3.

Berdasarkan data peramalan pasar dan hasil survey lapangan, dapat diketahui pengguna potensial layanan interactive games dengan memperhatikan faktor usia produktif dan sekolah (usia 15-64 tahun) yaitu 22.7\% persen dari total pengguna layanan data. Berdasarkan data tersebut, pengguna potensial game interaktif di wilayah Bandung seperti yang ada pada Tabel 4.

TABEL 4

Peramalan PengGuna Potensial Interactive Games(IG)

\begin{tabular}{|r|r|}
\hline Tahun & Pengguna potensial IG \\
\hline 2016 & 1.141 .154 \\
\hline 2017 & 1.357 .723 \\
\hline 2018 & 1.615 .403 \\
\hline 2019 & 1.921 .980 \\
\hline 2020 & 2.286 .743 \\
\hline
\end{tabular}

Berdasarkan peramalan pengguna potensial games interative, pengguna dapat dibagi menjadi dua kelas segmentasi, yaitu segmentasi bisnis dan residensial. Segmentasi pengguna terbagi menjadi dua, yaitu pengguna bisnis dan residensial dengan asumsi dan pendekatan yang telah dijelaskan sebelumnya. Dalam penelitian ini, asumsi untuk pengguna bisnis adalah $22,5 \%$ dan pengguna reseidensial 77,5\%. Asumsi ini berdasarkan pada jumlah industri yang ada di Bandung. Segmentasi bisnis diketahui berdasarkan prosentase sektor industri besar dan menengah, sedangkan residensial berdasarkan prosentase kecil yang ada di Bandung.

TABEL 5 PERHITUNGAN PERAMALAN PENGGUNA IG MASING-MASING SEGMEN

\begin{tabular}{|c|c|r|}
\hline Tahun & Bisnis & Residensial \\
\hline 2016 & 285.289 & 855.866 \\
\hline 2017 & 339.431 & 1.018 .292 \\
\hline 2018 & 403.851 & 1.211 .552 \\
\hline 2019 & 480.495 & 1.441 .485 \\
\hline 2020 & 571.686 & 1.715 .058 \\
\hline
\end{tabular}

12
Asumsi prosentase pengguna bisnis diperoleh berdasarkan prosentase industri besar dan menengah, sedangkan untuk bisnis berdasarkan industri kecil. Sehingga pengguna potensial untuk masing-masing segmen diperoleh dari prosentase masing-masing segmen dari pengguna potensial IG. Hasil perhitungan segmentasi pengguna terdapat pada Tabel 5 .

\section{F. Aspek Teknis}

Pengembangan konten secara teknis tidak terlalu memerlukan pengadaan perangkat dan software yang kompleks dan mahal. Cukup dengan beberapa perangkat komputer dan beberapa software design grafis dan multimedia dapat mendukung pelaksanaan bisnis content development. Subjek inti dari bisnis kreatif khususnya ineraktif games ini adalah adanya programmer yang handal dan designer yang cerdas dan kreatif. Satu aplikasi games dapat dibuat dalam waktu 2 sampai dengan 3 bulan dari mulai riset pasar sampai peluncuran. Satu game dapat dibuat dan diselesaikan oleh satu tim yang terdiri dari periset, pendesign, pemrogram, dan pemasar. Satu tim dapat terdiri dari 2 sampai dengan 3 orang. Perangkat komputer dengan spesifikasi khusus yang mendukung pembuatan grafis dengan kemampuan rander grafis dan memory yang tinggi menjadi syarat lainnya yang harus ada.

\section{G. Aspek Finansial}

Perhitungan keuangan menggunakan beberapa data nyata dan asumsi standar yang diperoleh dengan beberapa cara, yaitu :

a. Observasi harga dengan media internet.

b. Referensi dari penelitan sebelumnya.

c. Benchmarking dengan industri sejenis yang sudah ada.

\section{H. Pendapatan}

Pendapatan adalah asumsi tarif yang diberlakukan ke pengguna, besarnya pendapatan diperoleh dari perkiraan jumlah demand layanan download IG dikalikan dengan tarif untuk setiap kali download. Besarnya asumsi tarif mengacu pada harga yang sudah ada yang diberlakukan diberlakukan ke pengguna, yaitu kelas Full level sebesar Rp 20.000,00 dan kelas Half Level Rp 10.000,00. Tarif yang diberlakukan untuk masing-masing layanan adalah flat selama masa peramalan. Dari hasil observasi dilapangan, setiap Interaktif game yang menarik rata-rata akan di download oleh sekitar 2 sampai dengan $5 \%$ pengguna layanan data.

\section{Biaya Investasi Perangkat}

Berdasarkan aspek teknis yang diperlukan dalam berinvestasi, maka perhitungan rincian biaya investasi perangkat dapat dilihat pada Tabel 6 .

Studi Kelayakan Bisnis Konten Kreatif Di Kota Bandung (Studi Kasus: PT Akses Nusa Karya Infratek) Siti Hajar Komariah, Dicky Hidayat (Hal: 7-15) 
TABEL 6

INVESTASI

\begin{tabular}{|r|l|r|r|}
\hline No & \multicolumn{1}{|c|}{ Komponen } & Volume x Harga & Total \\
\hline 1 & $\begin{array}{l}\text { Perangkat } \\
\text { Komputer }\end{array}$ & $10 \times 15.000 .000,00$ & $150.000 .000,00$ \\
\hline 2 & $\begin{array}{l}\text { Software } \\
\text { Aplikasi }\end{array}$ & 50.000 .000 & $50.000 .000,00$ \\
\hline & & & $200.000 .000,00$ \\
\hline
\end{tabular}

Umur pakai Komputer selama 5 tahun dengan Depresiasi perangkat $20 \%$ per tahun tanpa sisa, shingga depresiasi perangkat per tahun 30.000 .000 .

\section{J. Biaya Operasional}

Biaya operasional yang dikeluarkan dalam pembangunan dan pengembangan IG meliputi komposisi biaya sebagai berikut:

TABEL 7

KOMPOSISI BIAYA OPERASIONAL

\begin{tabular}{|r|l|r|}
\hline \multicolumn{1}{|c|}{ No } & \multicolumn{1}{|c|}{ Komponen } & \multicolumn{1}{c|}{ Biaya } \\
\hline 1 & Personel & Rp. 300.000 .000 \\
\hline 2 & Marketing & Rp. 40.000 .000 \\
\hline 3 & General dan Administration & Rp. 20.000 .000 \\
\hline
\end{tabular}

Perhitungan biaya operasional yang dikeluarkan meliputi :

1. Personal SDM Tim Pengembang Konten ( 3 tim) Biaya personel ditetapkan Rp. 300.000.000. Biaya personel ini digunakan untuk membayar gaji kepada karyawan PT ANK. Biaya SDM naik $10 \%$ setiap tahun.

2. Riset dan Marketing

Biaya untuk pemasaran digunakan untuk melakukan promosi yang terdiri dari pembuatan brosur, sponsorship, biaya iklan di radio, majalah maupun pembuatan merchandise. Biaya untuk marketing diasumsikan sebesar Rp. 40.000.000.

3. General \& Administration

Biaya administrasi dan umum meliputi biaya perlengkapan kantor, biaya fotokopi dan biaya personel. Biaya general dan administrasi diasumsikan Rp. 20.000.000.

\section{HASIL DAN ANALISA}

A. Pendapatan

Pendapatan diperoleh dengan menghitung sebanyak $60 \%$ pengguna bisnis akses layanan IG Full Level dan Residential $40 \%$ pengguna di kalikan dengan tarif layanan Rp 20.000.000 per sekali download.

TABEL 8

PENDAPATAN IG

\begin{tabular}{|c|c|c|c|}
\hline Tahun & Bisnis & Residensial & Pendapatan \\
\hline 2017 & 285289 & 855866 & $\mathrm{Rp} 365,169,580.00$ \\
\hline 2018 & 339431 & 1018292 & $\mathrm{Rp} 434,471,340.00$ \\
\hline 2019 & 403851 & 1211552 & $\mathrm{Rp} 516,928,940.00$ \\
\hline 2020 & 480495 & 1441485 & $\mathrm{Rp} 615,033,600.00$ \\
\hline 2021 & 571686 & 1715058 & $\mathrm{Rp} 731,758,080.00$ \\
\hline
\end{tabular}

Dari perolehan layanan half level, didapat dengan perhitungan 90 persen residential mendownload half level dan $10 \%$ Kelas bisnis mengakses half level juga dengan tarif Rp. 10.000 .

B. Beban Operasional

Beban operasional terdiri dari beban SDM (personel, berupa gaji dll) sebesar Rp. 300.000 .000 per tahun dan biaya marketing, riset dan administrasi sebesar Rp.60.000.000 per tahun. Diasumsikan ada kenaikan beban $10 \%$ per tahun

TABEL 9

BEBAN IG

\begin{tabular}{|l|l|l|}
\hline Tahun & Pendapatan & Beban \\
\hline 2017 & Rp365,169,580.00 & Rp360,000,000.00 \\
\hline 2018 & Rp434,471,340.00 & Rp396,000,000.00 \\
\hline 2019 & Rp516,928,940.00 & Rp435,600,000.00 \\
\hline 2020 & Rp615,033,600.00 & Rp479,160,000.00 \\
\hline 2021 & Rp731,758,080.00 & Rp527,076,000.00 \\
\hline
\end{tabular}

C. Perhitungan Net Present Value, Pay Back Periode, dan Internal Rate of Return

Untuk menentukan kelayakan bisnis konten kreaif di Bandung ini, perlu dilakukan perhitungan Net Peresent Value, Internal Rate of Return dan Pay back Periode. 
TABEL 10

Perhitungan Net Present Value, Pay Back Periode, DAN Internal Rate of Return

\begin{tabular}{|c|c|c|c|c|c|c|}
\hline Item Perhitungan & 2016 & 2017 & 2018 & 2019 & 2020 & 2021 \\
\hline Investasi ( CAPEX) & Rp200,000,000 & & & & & \\
\hline Gaji Personel & & $\begin{array}{r}\mathrm{Rp} 300,000,00 \\
0 \\
\end{array}$ & Rp330,000,000 & Rp363,000,000 & Rp399,300,000 & Rp439,230,000 \\
\hline $\begin{array}{l}\text { Operasional } \\
\text { (OPEX) }\end{array}$ & & Rp60,000,000 & Rp66,000,000 & Rp72,600,000 & Rp79,860,000 & $\mathrm{Rp} 87,846,000$ \\
\hline Depresiasi & & $\mathrm{Rp} 30,000,000$ & $\mathrm{Rp} 30,000,000$ & Rp30,000,000 & $\mathrm{Rp} 30,000,000$ & Rp30,000,000 \\
\hline Total Usaha & & $\begin{array}{r}\mathrm{Rp} 390,000,00 \\
0\end{array}$ & Rp426,000,000 & Rp465,600,000 & Rp509,160,000 & Rp557,076,000 \\
\hline Pendapatan & & $\begin{array}{r}\mathrm{Rp} 365,169,58 \\
0 \\
\end{array}$ & $\mathrm{Rp} 434,471,340$ & Rp516,928,940 & Rp615,033,600 & Rp731,758,080 \\
\hline BV $(7-1-6)$ & -Rp200,000,000 & -Rp24,830,420 & $\mathrm{Rp} 8,471,340$ & Rp51,328,940 & Rp105,873,600 & Rp174,682,080 \\
\hline Inflasi(6\%) & & -Rp1,489,825 & Rp508,280 & $\mathrm{Rp} 3,079,736$ & Rp6,352,416 & $\mathrm{Rp} 10,480,925$ \\
\hline $\begin{array}{l}\text { Arus kas sebelum } \\
\text { pajak }(8+9)\end{array}$ & & -Rp26,320,245 & $\mathrm{Rp} 8,979,620$ & Rp54,408,676 & Rp112,226,016 & Rp185,163,005 \\
\hline $\begin{array}{l}\text { Laba sebelum } \\
\text { Pajak(7-6) }\end{array}$ & & -Rp24,830,420 & $\mathrm{Rp} 8,471,340$ & Rp51,328,940 & Rp105,873,600 & Rp174,682,080 \\
\hline Pajak(15\%) & & -Rp3,724,563 & $\mathrm{Rp} 1,270,701$ & $\mathrm{Rp} 7,699,341$ & $\mathrm{Rp} 15,881,040$ & $\mathrm{Rp} 26,202,312$ \\
\hline $\begin{array}{l}\text { Laba sesudah } \\
\text { pajak(11-12) }\end{array}$ & & -Rp21,105,857 & $\mathrm{Rp} 7,200,639$ & Rp43,629,599 & Rp89,992,560 & Rp148,479,768 \\
\hline $\begin{array}{l}\text { Arus kas sesudah } \\
\text { pajak }(10-12)\end{array}$ & & -Rp22,595,682 & $\mathrm{Rp} 7,708,919$ & $\mathrm{Rp} 46,709,335$ & Rp96,344,976 & Rp158,960,693 \\
\hline Faktor bunga ( $12 \%)$ & & 0.892857143 & 0.797193878 & 0.711780248 & 0.635518078 & 0.567426856 \\
\hline NPV & & -Rp18,844,515 & Rp5,740,305 & $\mathrm{Rp} 31,054,687$ & Rp57,191,899 & $\mathrm{Rp} 84,251,408$ \\
\hline NPV Kumulatif & & -Rp18,844,515 & -Rp13,104,210 & Rp17,950,477 & Rp75,142,376 & Rp159,393,784 \\
\hline
\end{tabular}

Dari Tabel 10 dapat dilihat hasil perhitungan sebagai berikut:

NPV : Rp 159393.784 (Positif)

Pay back periode : 3,67 Tahun (lebih kecil dari waktu pakai alat)

IRR : lebih besar dari $12 \%$

Berdasarkan hasil tersebut, bisnis konten kreatif di bandung layak untuk dilaksanakan.

\section{KESIMPULAN}

Bisnis konten kreatif di Bandung terus berkembang dengan pesat, dengan di dukung oleh layanan data operator berbasis layanan 3G dan 4G (LTE). Potensi pasar layanan konten kreatif khususnya interactive games sangat besar dengan perkiraan $22,7 \%$ dari total pengguna layanan data internet. Berdasarkan hasil perhitungan beberapa parameter kelayakan bisnis seperti Net Present Value, Internal Rate of Return, dan Pay back periode, diperoleh nilai-nilai yang menunjukkan bisnis konten kreatif di Bandung cukup menjanjikan dan layak untuk di gelar.

\section{DAFTAR PUSTAKA}

[1] Ariestonandri, Prima., 2006., "Marketing Research for Beginner", Yogyakarta: Penerbit Andi.

[2] Bianchini, Charles., 2010., "The Creative City"., Demos.

[3] DCMS., (2001)., "Creative Industries Mapping Document". second ed., London., UK: Department of Culture., Media and Sport.

[4] Florida, Richard, The Rise of the Creative Class. And How It's Transforming Work, Leisure and Everyday Life, Basic Books

[5] Hesmondhalgh, David., 2002., "The Cultural Industries"., SAGE.

[6] Hidayat, Dicky \& Komariah, Siti Hajar., 2015., "Pengukuran Tingkat Pengenalan Pengguna Games Terhadap Muatan Budaya Indonesia Pada Mobile Game Berbasis Android”. Fakultas Industri Kreatif., Universitas Telkom.

[7] Howkins, John., 2012., "The Creative Economy: How People Make Money from Ideas"., Penguin.

[8] Martono, Apri., Indra, 2014, Analisa Investasi Dan Studi Kelayakan Proyek Pembangunan Perumahan Griya Asri Di

Studi Kelayakan Bisnis Konten Kreatif Di Kota Bandung (Studi Kasus: PT Akses Nusa Karya Infratek) Siti Hajar Komariah, Dicky Hidayat (Hal: 7-15) 
Karanganyar,Universitas Muhammadiyah Surakarta.

[9] Pandanwangi, Nurina., 2016.,Studi Kelayakan Rencana Pendirian Pop Hotel Di Yogyakarta

Oleh PT. Heidi Cahaya Berkat, Universitas Muhammadiyah Surakarta. 